\title{
Titae
}

33 (2018) 179-202

\section{Michał Klukowski}

Katolicki Uniwersytet Lubelski Jana Pawła II, Lublin

michael.klukowski@yahoo.com, ORCID:0000-0003-1130-7406

\section{ROZDARCIE SZAT ARCYKAPŁANA}

A ROZDARCIE ZASŁONY ŚWIĄTYNI

JAKO WYRAZ GNIEW U CZŁOWIEKA I BOGA

w Ewangelin Mateusza (Mт 26,65; 27,51)

The Tearing of the High Priest's Robes and of the Temple Curtain as Expressions of Human and Divine Anger in Matthew's Gospel $(26,65 ; 27,51)$

W Ewangelii Mateusza znajdujemy dwa teksty, w których wspominany jest akt rozdarcia. Pierwszym z nich jest rozdarcie szat arcykapłana na usłyszane z ust Jezusa bluźnierstwo $(26,65)$. Drugim rozdarcie zasłony świątyni przez Boga (27,51). W artykule zostaje postawiona hipoteza, że rozdarcie zasłony świątyni było symbolicznym aktem Boga w odpowiedzi na rozdarcie szat przez arcykapłana. Świadectwa starotestamentowe poświadczają, że rozdarcie szat było wyrazem gniewu na usłyszane bluźnierstwo. Chociaż rozdzieranie szat było kapłanom zabronione (Kpł 10,6; 21,10), to jednak Miszna dopuszczała taką możliwość w czasie procesu przed 
Sanhedrynem. Możliwe, że Mateusz widział w rozdarciu zasłony świątyni symboliczne rozdarcie szaty Boga jako wyraz Jego gniewu na bluźnierstwo, którym było zabicie Jego Syna. Tym bardziej, że Mateusz akcentuje rozdarcie zasłony od góry do dołu, tymczasem właśnie szaty arcykapłana miały być tak rozrywane według przepisów Miszny. Trudnością wysuniętej hipotezy są dwa fakty. Po pierwsze, redakcja Miszny jest późniejsza od redakcji Ewangelii Mateusza. Po drugie, Mateusza używa dwóch różnych czasowników na opisanie aktu rozdarcia.

There are two passages about acts of tearing in the Gospel of Matthew. The first one is when the High Priest tore his robes after hearing supposed blasphemy against God from Jesus' mouth $(26,65)$, and the second when the Temple curtain was torn in two from top to bottom $(27,51)$. In this article I try to show that the tearing of the Temple curtain was God's response to the previous act of the High Priest tearing his robes. The Old Testament tradition confirms that the tearing of clothes was a sign of grief or anger in response to blasphemy. Although the tearing of the Priest's robes was forbidden by the Law (Lev 10:6; 21:10), the Mishnaic tradition testifies that the High Priest could have torn his robes immediately after hearing a blasphemy against God. It is possible that Matthew saw in the Temple curtain a sort of symbolic image of the robes of God, and that by tearing this curtain God expressed his grief and anger towards blasphemy against himself, i.e. the mocking and cursing of his Son. It is

God's anger; tearing of the robes; Temple curtain; blasphemy 
interesting that the curtain was torn in two from top to bottom, just like the Mishnah specifies that the High Priest had to tear his robe from top to bottom. There are two possible problems challenging my hypothesis. First, the Mishnah (though undoubtedly containing earlier traditions) is a later work than the Gospel of Matthew. Secondly, Matthew employs two different verbs to describe the acts of tearing, the priestly robe versus the veil.

Na kartach Ewangelii Mateusza akt „rozdarcia” pojawia się w dwóch miejscach: najpierw w trakcie przesłuchania Jezusa przed Sanhedrynem, kiedy to arcykapłan w odpowiedzi na bluźnierstwo Jezusa rozdziera szaty $(26,65)$, a następnie zaraz po śmierci Jezusa, po której następuje seria wydarzeń o charakterze kosmicznym, poprzedzona rozdarciem zasłony świątyni (27,51). Teza wyjściowa artykułu jest następująca: o ile rozerwanie szat przez arcykapłana było wyrazem gniewu ludzkiego w odpowiedzi na (rzekome) bluźnierstwo Jezusa przeciw Bogu, o tyle rozdarcie zasłony świątyni stanowi wyraz Bożego gniewu w odpowiedzi na (faktyczne) bluźnierstwo przeciw Bogu, jakim było zabicie Jego umiłowanego Syna (Mt 3,17; 12,18). Celem artykułu jest udzielenie odpowiedzi na pytanie, czy taka korelacja mogła być zamierzona przez samego Mateusza. Realizacja celu pracy będzie przebiegać w następującym porządku: w pierwszej kolejności uwaga zostanie skupiona na motywie rozdarcia szat przez arcykapłana, następnie analizie zostanie poddany motyw rozdarcia zasłony świątyni, po której z kolei nastąpi porównanie obu scen w celu wykazania ich potencjalnych paraleli. 


\section{Rozdarcie szat arcykapeana (Mt 26,65)}

\subsection{Kontekst literacki Mt 26,65}

Jak zostało już zasygnalizowane we wstępie, akt rozdarcia szat arcykapłana znajduje się w kontekście przesłuchania Jezusa przed Sanhedrynem. Początkowo arcykapłan i Sanhedryn na próżno szukali fałszywego świadectwa, na bazie którego mogliby skazać Jezusa na śmierć (26,59-60). Pretekstem do dalszych poszukiwań okazali się dwaj świadkowie, którzy paradoksalnie złożyli prawdziwe świadectwo, mianowicie przytaczając słowa Jezusa o tym, że jest on w stanie zburzyć świątynię i odbudować ją w trzy dni $(26,61)$. Jezus zapytany przez arcykapłana, dlaczego nie odpowiada na usłyszane zarzuty, postanawia milczeć $(26,62)$, czym w oczach Sanhedrynu pośrednio potwierdza prawdziwość stawianego Mu zarzutu. Następnie arcykapłan zmusza Jezusa, aby pod przysięgą przyznał, czy jest On faktycznie Mesjaszem, Synem Boga $(26,63)$. Jezus odpowiada dosłownie „Ty powiedziałeś”, co u Mateusza wiąże się z pozytywną odpowiedzią (por. 26,25; 27,11). Sam tytuł „Mesjasz” nie był jednak wystarczającym dla oddania prawdziwej tożsamości Jezusa, dlatego zostaje on dookreślony przez słowa oparte o Dn 7,14 i Ps 110,1: "Odtąd ujrzycie Syna Człowieczego, siedzącego po prawicy Wszechmocnego, i nadchodzącego na obłokach niebieskich" (Mt 26,64). Na te słowa arcykapłan rozdarł swe szaty, stwierdzając dwukrotnie, że są one bluźnierstwem $(26,65)$. Następnie arcykapłan pyta o zdanie całą resztę zgromadzenia, ci zaś potwierdzają jego ocenę, wskazując na karę, jaką Jezus powinien ponieść: „winien jest śmierci” $(26,66)$. Kolejne dwa wersety zamykają scenę przesłuchania, opisując znęcanie się nad Jezusem poprzez plucie, bicie i naśmiewanie się z Niego (26,67-68). 


\subsection{Rozdarcie szat arcykapłana na tle tradycji starotestamentowych}

Rozdarcie szat jest na kartach ST związane z wyrażeniem żalu i rozpaczy, zwłaszcza na wieść o śmierci ważnej i umiłowanej osoby, np. syna. Jakub rozdarł swoje szaty na wieść o rzekomej śmierci jego syna, Józefa (Rdz 37,34), podobnie jak wcześniej uczynił to Ruben ( $\mathrm{Rdz} 37,29)$, a potem inni bracia w reakcji na utratę ich najmłodszego brata $(\operatorname{Rdz} 44,13)$. Dawid z kolei rozdarł swe szaty na wieść o śmierci Saula i jego syna, Jonatana (2 Sm 1,11-12).

Gest rozdarcia szat w tym kontekście znany jest także w kulturze grecko-rzymskiej. Kasjusz Dion w swej Historii rzymskiej (54, 14, 1-2) wspomina Liciniusa Regulusa, który dowiedziawszy się, że nie znajduje się na liście wybranych członków, publicznie rozdarł swoje ubranie w rzymskim senacie. Dalej Kasjusz Dion podaje, że również cezar August rozdarł ze złości ubranie, kiedy dowiedział się o porażce Publiusza Kwintyliusza Warusa w bitwie w lesie Teutoburskim $(56,23,1)$.

Jednak w kontekście rozdarcia szat przez arcykapłana najważniejsze wydają się teksty dotyczące bluźnierstwa i przepisów kapłańskich. Gest rozdarcia szat w reakcji na usłyszane bluźnierstwo wobec Boga poświadczony jest w Drugiej Księdze Królewskiej. Kiedy dowódca wojsk asyryjskich zbluźnił przeciwko Bogu YHWH poprzez stwierdzenie, iż nie będzie On w stanie zapobiec oddaniu Jerozolimy w ręce króla asyryjskiego (2 Krl 18,30), na te słowa Eliakim i jego towarzysze rozdarli swe szaty ( $\mathrm{Krl} 18,37)$, a następnie król Ezechiasz (2 Krl 19,1), któremu przekazali te słowa (por. Iz 36,22-37,1).

W przypadku przepisów odnoszących się bezpośrednio do kapłanów, w Kpł 10,6 Mojżesz przykazuje Aaronowi i jego synom, aby nie rozdzierali swych szat, tak aby i Pan nie rozgniewał się i nie ukarał ich śmiercią. Ten sam nakaz zostaje powtórzony w Kpł 21,10. Ponieważ Kpł 10,6 znajduje 
się w kontekście przepisów dotyczących posługi kapłańskiej, można zakładać, że mowa tu o szatach kapłańskich. Z kolei Kpł 21 dotyczy wprost arcykapłana. Co istotne, LXX w obu księgach ( $2 \mathrm{Krl}$ i Kpł) na oddanie szat używa terminu i $\mu \alpha \dot{\tau} \iota 0 \nu$, czynność rozdarcia szat zaś oddaje przez czasownik $\delta \iota \propto p \eta ́ \gamma \nu \nu \mu \iota$, a zatem zostają użyte dwa terminy, których również Mateusz używa w kontekście rozdarcia szat przez arcykapłana (Mt 26,65, inaczej Mk 14,63).

Podsumowując, zarówno na kartach ST, jak i w dziełach historyków rzymskich, gest rozdarcia szat był przede wszystkim związany z wyrazem rozpaczy i żalu na wieść o utracie bliskiej i kochanej osoby bądź też na wieść o porażce w szeroko rozumianym tego słowa znaczeniu. Gest ten wyrażał także gniew na usłyszane bluźnierstwo. Pomimo, że rozdarcie szat było dość znanym i praktykowanym aktem wyrażania emocji, to, jak pokazują teksty z Kpł 10,6 i 21,10, kapłanom było zabronione rozdzieranie ich szat.

\subsection{Rozdarcie szat arcykapłana jako wyraz gniewu}

Podczas gdy Marek przedstawia akt rozdarcia szat za pomo-

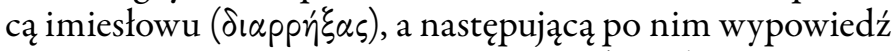
wprowadza czasownikiem aktywnym ( $\lambda \dot{\varepsilon} \gamma \varepsilon \iota)$, to Mateusz odwraca ten porządek, wprowadzając wypowiedź imiesłowem $(\lambda \varepsilon ́ \gamma \omega \nu)$, a sam akt opisując formą aktywną czasownika $(\delta เ \varepsilon \dot{p} p \eta \xi \varepsilon v)^{1}$. Dla Marka więc rozdarcie szat bardziej towarzyszy słowom, gdy tymczasem u Mateusza słowa towarzyszą temu gestowi. Ta różnica akcentów nie może ujść naszej uwadze w dalszej części artykułu. Ponadto na uwage zasługuje fakt, że Marek mówi o rozdarciu tuniki $(\chi \imath \tau \omega \nu)$, czyli spodniej szaty, Mateusz natomiast mówi o zewnętrznej szacie (i $\mu \alpha \dot{\tau}(\circ)$ ). Istotne dla nas jest to, że użyty przez obu ewangelistów czasownik $\delta \iota \alpha p \eta ́ \gamma \gamma v \mu \iota$ prawie zawsze w LXX

1 Łukasz w swojej relacji pomija wątek rozdarcia szat przez arcykapłana. 
łączy się w kontekście rozdarcia odzienia z terminem użytym przez Mateusza, prawie w ogóle natomiast nie łączy się z terminem użytym przez Marka - występuje zaledwie trzy razy i nigdy w kontekście bluźnierstwa (por. 2 Sm 15,32; $1 \mathrm{Krl}$ 20,27; 4 Mch 9,11). A to właśnie usłyszane bluźnierstwo było przyczyną rozdarcia szat przez arcykapłana, w czym zgodni są tak Mateusz, jak i Marek.

Jak pokazują przeprowadzone przez R.E. Browna analizy greckiego „rdzenia” $\beta \lambda \alpha \sigma \phi \eta \mu-$ w LXX oraz dziełach Filona i Flawiusza, bluźnierstwo co najmniej do czasów Jezusa odnosiło się do czterech możliwych działań człowieka²: (1) naśmiewanie się z Boga, (2) przeklinanie Boga, (3) lekceważenie i umniejszanie mocy Boga, (4) przypisywanie sobie cech i przywilejów, które należą wyłącznie do Boga. Biorąc pod uwagę te cztery możliwe kategorie, można zastanowić się, w oparciu o którą z nich arcykapłan uznał słowa Jezusa za bluźniercze. Jak zauważyliśmy wcześniej (pkt. 1.1.), z relacji Ewangelii Mateusza wynika, że za bluźnierstwo zostało uznane przypisanie sobie tytułu Mesjasza, Syna Bożego, a także odniesienie swojej osoby do postaci Syna Człowieczego z Dn 7,14, który zasiądzie „po prawicy Wszechmocnego, i nadchodzącego na obłokach niebieskich" (Mt 26,64). Na poziomie historycznym nie mamy pewności, który z tych trzech tytułów mógł nieść ze sobą bluźnierczą treść na początku trzeciej dekady I wieku po Chrystusie. Mamy jednak pewność, że żaden z nich nie mógł należeć do pierwszych trzech kategorii bluźnierstwa ${ }^{3}$. Jeśli więc arcykapłan uznał Jezusa za bluźniercę, to prawdopodobnie dlatego, że przypisał On sobie prerogatywy boskie. Rozstrzygnięcie problemu, który z tytułów mógł być bezpośrednim powodem rozdarcia szaty, nie jest istotne dla celu tego artykułu. Dla nas liczy się tu sam fakt, że akt rozdarcia szat był wyrazem gniewu arcykapłana na usłyszane bluźnierstwo, co z kolei łą-

2 Brown, The Death, 532.

3 Evans - Carlston, From Synagogue, 24-41, 48-58. 
czy motywację tego aktu ze wspomnianą wcześniej tradycją z 2 Krl 18,37 i 19,14.

W tym miejscu możemy przejść do pytania, czy arcykapłan był uprawniony do rozdarcia swoich szat. Otóż jak zostało wyżej zauważone (pkt 1.2.), Księga Kapłańska wyraźnie zabraniała kapłanom takich praktyk. Jednakże fakt istnienia takiego zakazu (Kpł 10,6 i 21,10) wcale nie musi rozstrzygać sprawy na rzecz uznania, że arcykapłan poprzez ten gest złamał Prawo Mojżeszowe (co Mateusz mógł ukazać jako ironię na tle oskarżeń wobec Jezusa). Tak naprawdę bowiem nie wiemy, jaki status posiadały wówczas przepisy kapłańskie zawarte w Pięcioksięgu, gdyż w ogóle nie możemy mieć pewności, która forma Pięcioksięgu była wówczas autorytatywna i jakiego rodzaju jej interpretacje były obowiązująces. Ponadto świadectwo Miszny z traktatu o Sanhedrynie wskazuje, że gest rozdarcia szat przez arcykapłana nie tylko był dopuszczalny, ale wręcz wymagany. Według Miszny, kiedy w czasie procesu zostanie wypowiedziane bluźnierstwo, potwierdzone przez świadków, wówczas sędziowie winni rozedrzeć swoje szaty i nigdy więcej już ich nie użyć (Sanhedryn 7, 5) ${ }^{6}$. Zgodnie $z$ innym traktatem Miszny (Horajot 3, 5), ten sam gest kapłani mogli uczynić w obliczu wieści o śmierci krewnego, przy czym w tym miejscu Miszna doprecyzowuje, iż kapłan wi-

4 Bluźnierstwo dowódcy wojsk asyryjskich $(2 \mathrm{Krl} 18,30)$ podchodzi pod trzecią kategorię bluźnierstwa.

5 Meier, „The Historical Jesus”, 52-79.

6 The Mishnah, 392: „«The blasphemer» is not culpable unless he pronounces the Name itself. R. Joshua b. Karha says: On every day [of the trial] they examined the witnesses with a substituted name, [such as] «May Jose smite Jose». When sentence was to be given they did not declare him guilty of death [on the grounds of evidence given] with the substituted name, but they sent out all the people and asked the chief among the witnesses and said to him, «Say expressly what thou heardest», and he says it; and the judges stand up on their feet and rend their garments, and they may not mend them again. And the second witness says, «I also heard the like», and the third says, «I also heard the like»". 
nien rozedrzeć swą szatę od dołu do góry, z kolei arcykapłan $z$ góry (na dół) (Horajot 3, 5, por. Mt 27,51) 7 . W tym miejscu kluczowy jest dla nas pierwszy tekst z Miszny, gdyż stanowi świadectwo o tym, że w czasie procesu przed Sanhedrynem rozdarcie szat było gestem w pełni uprawnionym, pomimo tradycji zachowanej w Księdze Kapłańskiej.

Choć oczywiście świadectwo Miszny jest późniejsze (początek III wieku po Chrystusie) w stosunku do Ewangelii Mateusza i może odnosić się zarówno do prawa obowiązującego przed lub po roku 70 po Chrystusie ${ }^{8}$, to jednak fakt, że instytucja Sanhedrynu była związana ściśle ze świątynią i środowiskiem kapłanów, pozwala nam przypuszczać, że mamy w niej do czynienia z tradycją przed rokiem 70, kiedy to jeszcze istniała świątynia' . Ponadto Miszna, przytaczając tradycję o bluźnierstwie wypowiedzianym przed Sanhedrynem, powołuje się na świadectwo rabbiego Jozuego ben Karha, który był uczniem rabbiego Akiby ben Josefa żyjącego w latach 50-132 po Chrystusie ${ }^{10}$, tak więc w latach ostatecznego redagowania Ewangelii Mateusza. Choć zatem historycznie nie mamy pewności, że prawa odnośnie do Sanhedrynu, które zawarte są w Misznie, odzwierciedlają historyczny przebieg procesu Jezusa, to jednak sam Mateusz mógł posiadać

7 The Mishnah, 465: „The High Priest rends his garment from below, but an ordinary priest from above".

8 Sanders, Jewish Law, 5.

9 J. Neusner (Judaism) dowodził, że jedynie przepisy odnośnie do czystości rytualnej pochodzą w Misznie sprzed roku 70. Założenia i podejście J. Neusnera, a w konsekwencji jego wnioski, zostały poddane krytyce przez E.P. Sandersa (Jewish Law, 332). Krótko ujmując problem, dla J. Neusnera Miszna stanowi swego rodzaju traktat filozoficzny ukazujący idealny judaizm i jego prawodawstwo, niekoniecznie mające wiele wspólnego z faktyczną tradycją z judaizmu okresu Drugiej Świątyni. Tymczasem E.P. Sanders zwraca uwagę, że Neusner w swych rozważaniach zlekceważył zupełnie kwestie gatunku literackiego Miszny, co jest podstawą dla właściwej oceny wartości historycznej Miszny.

10 Ginzberg, „Akiba ben Joseph”, 304-310. 
wiedzę o takiej tradycji (choćby fikcyjnej) i wykorzystać ją w budowaniu swojej narracji. W kontekście procesu przed Sanhedrynem Miszna wspomina również, że w przypadku przestępstw podchodzących pod karę śmierci proces i wydanie werdyktu musiało mieć miejsce w ciągu dnia, a ponadto nie mogło odbyć się w przeddzień święta $(\text { Sanhedryn } 4,1)^{11}$. Tymczasem według Mateusza właśnie o tym czasie roku zapadł wyrok śmierci na Jezusa, i to nocną porą, co świadczy o tym, że proces Jezusa przed Sanhedrynem miał charakter nieformalny. Potwierdzałby to także fakt, iż przesłuchanie Jezusa miało miejsce w rezydencji arcykapłana ${ }^{12}$, o której w żadnym z dostępnych nam źródeł historycznych nie wspomina się jako o miejscu oficjalnych spotkań Sanhedrynu ${ }^{13}$.

Oczywiście prawdą jest, że wiele przepisów Miszny dotyczących Sanhedrynu zupełnie nie przystaje do opisów z czterech Ewangelii, jednak trzeba wziąć pod uwagę wspomniany już fakt, że proces Jezusa miał prawdopodobnie charakter nieformalny, co mogło mieć wpływ na zignorowanie przepisów odnośnie do formalnego przebiegu procesu. Ponadto w przytoczonej argumentacji z tradycji Miszny chodzi głównie o zwrócenie uwagi, że na poziomie historycznym nie można wykluczyć faktu rozdarcia szat przez arcykapłana tylko dlatego, że Księga Kapłańska wyraźnie tego zabrania.

11 The Mishnah, 387: „In capital cases they hold the trial during the daytime and the verdict also must be reached during the daytime. [...] in capital cases a verdict of acquittal may be reached on the same day, but a verdict of conviction not until the following day. Therefore trials may not be held on the eve of a Sabbath or on the eve of a Festival-day".

12 Co sugeruje wzmianka, iż Piotr szedł za pojmanym Jezusem aż

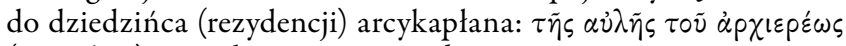
(Mt 26,58) - ewidentny genetivus loci.

13 Trudno jest jednoznacznie stwierdzić, gdzie dokładnie odbywały się spotkania Sanhedrynu w czasach publicznej działalności Jezusa, tym niemniej z dostępnych świadectw wydaje się, że było to miejsce umiejscowione raczej przy świątyni aniżeli w jej obszarze. Zob. Brown, The Death, 348-350. 


\subsection{Podsumowanie analizy tekstu Mt 26,65}

W ramach podsumowania wyróżnijmy najważniejsze dla nas rzeczy. Po pierwsze, Mateusz poprzez formę aktywną czasownika „rozdzierać” na tle występującego w tym wersie imiesłowu zwraca uwagę na ważność tego gestu. Po drugie, przy jego opisie używa języka LXX, odnosząc się do tradycji starotestamentowej. Po trzecie, w ramach tej tradycji odwołuje się on do aktu rozdzierania szat w obliczu gniewu na usłyszane bluźnierstwo wobec Boga. Po czwarte, w tym przypadku bluźnierstwem jest przypisywanie sobie przez Jezusa boskich prerogatyw. Wreszcie, pomimo wyraźnego zakazu Księgi Kapłańskiej, nie można całkowicie wykluczyć, że akt rozdarcia szat przez arcykapłana był dopuszczalny w świetle ówczesnych zwyczajów. W istocie bez względu na to, czy akt rozdarcia szat przez arcykapłana ma swoje uzasadnienie historyczne czy nie, Mateusz w oparciu o tradycje starotestamentowe ukazuje symboliczne znaczenie tego gestu jako wyrazu gniewu ludzkiego na usłyszane bluźnierstwo wobec Boga Izraela.

\section{Rozdarcie Zaseony świątyni (Mt 27,51)}

\subsection{Kontekst literacki Mt 27,51}

Rozdarcie zasłony świątyni w narracji Mateusza następuje zaraz po śmierci Jezusa. Zostaje ono wprowadzone przez czę-

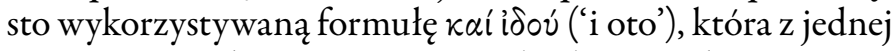
strony wprowadza nas w nowy wątek tekstu, a z drugiej strony ma na celu zwrócenie uwagi na następującą po niej sekwencję wydarzeń. W tym przypadku formula ta wprowadza wzmianke o rozdarciu zasłony świątyni i czterowiersz (27,51-52), który w formie biernej i za pomocą spójnika kai ('i, a’) krótko wylicza zjawiska, których przyczyną jest sam Bóg. Z kolei po czterowierszu następuje zmiana ze strony biernej na stronę 
aktywną, a także zmiana czasu akcji z wydarzeń następujących zaraz po śmierci Jezusa na wydarzenia zachodzące już po Jego wskrzeszeniu (27,53). Podział czasu akcji Mateusz zaznaczył wyrażeniem $\mu \varepsilon \tau \dot{\alpha} \tau \hat{\eta} \nu$ है $\gamma \varepsilon p \sigma \iota \nu$ a $\tau \tau o \tilde{v}$ ("po jego zmartwychwstaniu'). W tym świetle za zamkniętą jednostkę można uznać sam czterowiersz wraz z wprowadzeniem, w którym znajduje się interesująca nas wzmianka o rozdarciu zasłony świątyni. Strukturę tej jednostki można przedstawić następująco:

- wprowadzenie: „I oto zasłona świątyni została rozdarta" (27,51a);

- „i ziemia została potrząśnięta” (27,51b);

- „i skały zostały rozdarte” (27,51c);

- „i groby zostały otworzone” (27,52a);

- „i wiele ciał świętych w stanie snu zostało wskrzeszonych po Jego zmartwychwstaniu" (27,52b-53).

Jak widać powyżej, rozdarcie zasłony świątyni inauguruje zaistnienie kosmicznych wydarzeń prowadzących nas do punktu kulminacyjnego, czyli wskrzeszenia Jezusa, na mocy którego możliwe jest wskrzeszenie świętych do nowego życia.

\subsection{Kontekst teologiczno-historyczny Mt 27,51}

Pośród dostępnych nam tekstów judaizmu okresu Drugiej Świątyni nie znajdujemy nigdzie motywu rozdarcia zasłony świątyni, z wyjątkiem tekstów wczesnochrześcijańskich (zob. TestLew 10,3; EwPt 5,20) powstałych już po zburzeniu świątyni w roku 70 . Ten fakt sugeruje, że symboliczny obraz rozdartej zasłony świątyni prawdopodobnie narodził się na skutek tego dramatycznego wydarzenia dla Izraela. Oczywiście można również dopatrywać się oryginalności motywu rozdarcia zasłony w jego faktycznym zaistnieniu, jednakże na próżno szukać dowodów historycznych, które mogłyby potwierdzić tego rodzaju fakt ${ }^{14}$. Ponadto samo

14 Dostęp do miejsca, w którym znajdowała się zasłona, mieli wyłącznie kapłani. Tych zaś trudno podejrzewać o rozgłaszanie wieści o roz- 
wydarzenie zostaje opisane za pomocą języka i obrazów o charakterze eschatologicznym, co sugeruje, że tak właśnie należy podchodzić do tego tekstu. Jednak bez względu na historyczny czy ahistoryczny charakter tego zjawiska jego teologiczne znaczenie może być zrozumiane jedynie przy założeniu, iż wiemy, czym w istocie była zasłona świątyni i jakie przypisywano jej znaczenie.

Otóż, najkrócej mówiąc, zasłona świątyni stanowiła granicę między światem sacrum a profanum. Zasłona oddzielała najświętsze miejsce, w którym obecny był sam Bóg i do którego dostęp miał wyłącznie arcykapłan ${ }^{15}$. Prawdopodobnie w świątyni znajdowały się co najmniej dwie zasłony: wewnętrzna, która oddzielała miejsce najświętsze od świętego, oraz zewnętrzna, która oddzielała miejsce święte od dziedzińca świątyni. Ewangelie synoptyczne określają zasłonę terminem $\kappa \alpha \tau \alpha \pi \varepsilon ́ \tau \alpha \sigma \mu \alpha$, którym LXX określa zarówno zewnętrzną, jak i wewnętrzną zasłonę. Można wątpić, czy dla większości wczesnych chrześcijan szczegóły budowy świątyni były znane i czy różnica, o którą zasłonę mogło chodzić, stanowiła dla nich problem. Z pewnością część chrześcijan, głównie mam na myśli judeochrześcijan, miało świadomość znaczenia tej różnicy, o czym świadczy teologia Hbr 9,2-3 i 10,19-20. Nie można wykluczyć, że za ewangeliczną tradycją rozdarcia zasłony stała ta sama tradycja, która wpłynęła na teologię Listu do Hebrajczyków. Równie dobrze mogło być jednak odwrotnie. Bez względu na to, teologiczne znaczenie Mateuszowej wzmianki o rozdarciu zasłony świątyni wydaje się być jasne: tak jak wraz ze śmiercią Jezusa duch opuścił Jego ciało, tak również Bóg opuścił świątynie Jerozolimską, czego znakiem było rozdarcie przez Niego zasłony. Odtąd

darciu zasłony, gdyż ten boski znak byłby świadectwem przeciwko im samym. Gdyby z kolei przyjąć, że rozgłosili tę wieść, tak iż dotarła ona do pierwszych chrześcijan, to jak to możliwe, że dotarła ona bezpośrednio do chrześcijan, i tylko do nich, bez żadnego nawet echa w źródłach pozachrześcijańskich?

Meyers, „Veil of the Temple”, 9241. 
świątynia przestała być miejscem świętym, gdyż jej świętość gwarantowała jedynie obecność sa mego Boga. To dramatyczne wydarzenie, zarówno dla żydów, jak i judeochrześcijan, musiało odbić swoje piętno w ich świadomości i refleksji teologicznej (w tym Mateusza i jego wspólnoty). Skoro świątynia została zburzona, było oczywiste, że nie mógł w niej być obecny YHWH. Wydaje się, że wskazanie momentu opuszczenia świątyni przez Boga było dla chrześcijan czymś oczywistym, podobnie jak znaczenie tego aktu, jego przyczyna i nośnik emocjonalny. Na tych trzech aspektach skupimy się w kolejnym podpunkcie.

\subsection{Rozdarcie zasłony świątyni jako wyraz gniewu Bożego}

Zacznijmy od przypomnienia, że sam akt rozdarcia zasłony został wyrażony w stronie biernej, przy tym nie wskazując bezpośrednio na podmiot, co było semickim sposobem wskazania na Boga jako osobę dokonującą czynności (tzw. passivum theologicum/divinum). Nie ma więc wątpliwości, że za tym wszystkim stał Bóg. Kolejnym ważnym zabiegiem Mateusza jest ukazanie rozdarcia zasłony jako działania inaugurującego serię wydarzeń o charakterze eschatologicznym. Po tym, jak zasłona została rozdarta, nastąpiło trzęsienie ziemi, wskutek którego pękły skały, dzięki czemu ciała świętych ludzi mogły wyjść z grobowców skalnych, po tym jak zostali ożywieni. Rzecz jasna za tym wszystkim również stał Bóg, na co wskazuje dalsze użycie strony biernej przez Mateusza. W opisie tych kosmicznych wydarzeń istotne dla nas są dwie rzeczy. Po pierwsze, tego rodzaju obrazy służyły prorokom starotestamentowym dla zapowiedzi Bożego sądu jako jego widzialne znaki dla Izraela ${ }^{16}$. Sąd Boży zaś w ówczesnej mentalności wiązał się z Bożym gniewem, czego świadectwem są choćby teksty św. Pawła (np. Rz 2). Po

16 Por. Iz 5,25; 6,4; 24,18; Jr 4,23; Ez 38,19; Jl 2,10. 
drugie, przy opisie tych znaków Mateusz za sprawą wyraże-

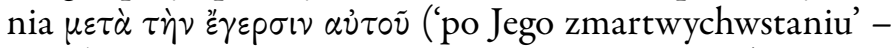
27,53) dzieli je na te o charakterze negatywnym (związane z eschatologicznym sądem - 27,51) i te o charakterze pozytywnym (zmartwychwstanie w ciele - 27,52-53). Rozdarcie zasłony należy do znaków negatywnych właśnie ze względu na gniew Boga i jego skutek. Skutkiem rozdarcia zasłony zaś, a zarazem przyczyną, jest opuszczenie przez Boga świątyni. Nieobecność Bożej chwały w świątyni, mówiąc językiem proroka Ezechiela, ostatecznie doprowadziło do jej zburzenia przez Rzymian, co również było odczytane jako gniew Boga. W świetle powyższych spostrzeżeń nie można stanowczo wykluczyć, że rozdarcie zasłony świątyni mogło być wyrazem Bożego gniewu, fakt zaś, że jego wyrażenie nastąpiło dokładnie zaraz po śmierci Jezusa, każe nam to widzieć jako jego bezpośrednio przyczynę.

W samym opisie rozdarcia zasłony Mateusz pozostawił nam szczegóły, wobec których nie można przejść obojętnie. Przede wszystkim wspomina o tym, że zasłona została rozdarta „z góry do dołu” na dwie części. Od razu powinno nasunąć się nam pytanie, dlaczego ewangelista w ogóle wtrącił tutaj ten szczegół. Dlaczego po prostu nie napisał, że zasłona została rozdarta, lecz ważne dla niego było podkreślenie, że stało się to „z góry do dołu”? Słowo „podkreślenie” nie jest tu użyte na wyrost. Można bowiem zauważyć, że o ile Marek w swojej relacji o rozdarciu zasłony najpierw wspomina o tym, że rozdarła się na dwoje, a potem dopiero, że stało się to z góry do dołu, o tyle Mateusz znowu odmiennie kładzie akcent w paralelnym tekście i czyni to na odwrót. Dla Mateusza więc ważniejsza jest wzmianka o rozdarciu „z góry do dotu". Dlaczego jednak ten szczegół był tak ważny dla obu ewangelistów ${ }^{17}$ Szukając odpowiedzi na to pytanie, jesteśmy w trudnym położeniu, ponieważ w całej tradycji przedchrześcijańskiej, włączając w to ST czy apokryfy, nie znajdujemy

17 Łukasz pomija ten szczegól. 
nigdzie takiej paraleli. Najbliżej czasów ewangelii Mateusza znajdujemy taki motyw jedynie we wspomnianej już w tym artykule Misznie. Otóż jak wcześniej zostało podkreślone (pkt 1.3.), Miszna uznawała możliwość rozdzierania szat przez kapłanów i arcykapłana. Jednakże, o ile kapłani mieli obowiązek rozdzierać szaty od dołu do góry, o tyle arcykapłani winni to czynić „z góry do dotu” (Horajot 3, 5). Biorąc pod uwagę, że Miszna została spisana między 100 a 150 lat po Ewangelii Mateusza (i Marka), nie można wykluczyć, że spisana tradycja tego zwyczaju sięgała czasów ewangelistów i ta wyjątkowa paralela znajduje swoje źródło w tej samej tradycji. Co mogłoby to w konsekwencji oznaczać? Być może Mateusz czyni tu właśnie aluzję do szaty, którą zasłona świątyni ma symbolizować na zasadzie metafory. Podobnie więc jak szata oddziela i zasłania to, co najbardziej dla człowieka intymne, sekretne i przysługujące jedynie oblubienicy, tak zasłona świątyni oddzielała to, co w oczach Boga było niedostępne dla świata profanum i przysługiwało jedynie Jego oblubienicy - Izraelowi. Możliwą paralelę sugeruje również fakt, że już sama wzmianka o rozdarciu zasłony automatycznie kieruje myśl na osobę arcykapłana, gdyż jedynie on miał dostęp do najświętszego miejsca. Powtórzmy jednak - Mateusz mógł to zasugerować tylko przy założeniu, że wzmianka o rozdarciu „z góry do dotu” jest odzwierciedleniem jedynej takiej tradycji zawartej w Misznie. Na koniec tej analizy należy wspomnieć inny bardzo ważny szczegół, mianowicie użycie przez Mateusza czasownika $\sigma \chi i \zeta \omega$ na opisanie rozdarcia zasłony. Czasownik ten na kartach LXX i NT ma bardzo różne zastosowanie ${ }^{18}$, ale w tym kontekście

18 W LXX tego czasownika używa się do wyrażenia: rąbania drzewa (Rdz 22,3; 1 Sm 6,14; Syr 10,9), rozstąpienia wód w czasie Exodusu (Wj 14,21), podziału (grup) ludzi (1 Mch 6,45), przecięcie powietrza (Mdr 5,11), rozdarcie szat (Iz 36,22; 37,1), pęknięcia/rozszczepie-

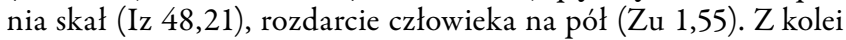
w NT jest on używany w kontekście: rozdarcia zasłony (Mt 27,51; Mk 15,38; Łk 23,45), pęknięcia/rozszczepienia skał (Mt 27,51), 
widzę jego potrójne znaczenie. Po pierwsze, podobnie jak rozdarcie nieba wskazuje na zstąpienie Ducha Bożego (por. Mk 1,10; Mt 3,16), który przedziera się z przestrzeni Bożej do przestrzeni ludzkiej (wedle semickich wyobrażeń świata), tak rozdarcie zasłony staje się widzialnym znakiem, że chwała Boża opuściła świątynię Jerozolimską. Duch Boży powrócił tam, dokąd udał się duch Jezusa. Dlatego właśnie wzmianka o opuszczeniu ducha Jezusa w momencie Jego śmierci znajduje się zaraz przed informacją o rozdarciu zasłony. Po drugie, czasownik $\sigma \chi i \zeta \omega$ sugeruje, że od momentu opuszczenia świątyni przez Boga został przypieczętowany radykalny rozdźwięk w relacji pomiędzy Bogiem a ludem Izraela. Odtąd ludem Boga nie będzie już etniczny Izrael zgromadzony wokół świątyni, lecz do Jego rodziny zostaną zaproszone wszystkie narody (Mt 28,19), sami stanowiąc Jego świątynię w Duchu Świętym (1 Kor 3,16; 6,16). Po trzecie, biorąc pod uwagę, że wspomniany czasownik jest także używany w kontekście rozdarcia szat (zob. Iz 36,22; $37,1 \mathrm{w}$ wersji LXX), może on w tym miejscu stanowić aluzję do rozdarcia szat arcykapłana. W ten sposób byłby to wyraz gniewu Boga, którego przyczyną jest zabicie Jego umiłowanego Syna (Mt 3,17; 12,18), a który zarazem skierowany jest na siły zła, które za tą śmiercią stały. Skutkiem tego gniewu Boga będzie ostateczne zwycięstwo nad nimi, kiedy Bóg wskrzesi Jezusa z martwych. Te trzy zaproponowane przeze mnie znaczenia aktu rozdarcia zasłony świątyni wskazują na jego trzy różne aspekty. Pierwsze znaczenie wskazuje na sam fakt tego wydarzenia, które staje się widzialnym znakiem realnego opuszczenia świątyni przez Boga. Drugie znaczenie wskazuje na skutek tego faktu. Trzecie znaczenie z kolei ukazuje jego przyczynę - cierpliwość Boga przelała swoją czarę, nieuchronny gniew Boga ostatecznie został wylany

rozstąpienia nieba $(M k 1,10)$, rozdarcia szat $(£ k$ 5,36(2x); J 19,24), rozdarcia sieci $(\mathrm{J} 21,11)$, rozdźwięku w relacjach międzyludzkich (Dz 14,4; 23,7). 
na złowrogie siły, a ostatecznym znakiem zwycięstwa będzie wskrzeszenie Jego Syna.

\subsection{Podsumowanie analizy tekstu 27,51}

Rozdarcie zasłony świątyni zostało opisane przez Mateusza językiem proroków jako wydarzenie o charakterze eschatologicznym, towarzyszące sądowi Bożemu, zainicjowane przez samego Boga. Akt ten dokonuje się zaraz po śmierci Jezusa, która jawi się jako bezpośrednia przyczyna wyrażonego przez Boga gniewu. Mateusz akcentuje przy tym w strukturze całego wersu rozdarcie zasłony z góry do dołu, czym być może czyni aluzję do zwyczaju rozdzierania szat przez arcykapłana, o czym wspomina Miszna. Nie znajdujemy bowiem innej paraleli dla tego szczegółu. Pozostaje także kwestią otwartą znaczenie użycia czasownika $\sigma \chi i \zeta \omega$ dla czynności rozdarcia zasłony. Wydaje się, że może ono wskazywać zarówno na przyczynę aktu rozdarcia, tj. gniew Boga, który rozdziera zasłonę niczym szatę, jak również na skutek, czyli opuszczenie świątyni i złamanie dotychczasowej relacji Boga z Izraelem, skupionej wokół kultu świątynnego.

\section{RozDARCIE SZAT A ROZDARCIE ZASEONY - ANALIZA PORÓWNAWCZA}

Porównując obie powyżej analizowane sceny, możemy dostrzec pomiędzy nimi kilka istotnych paraleli. Po pierwsze, znajdują się one w kontekście relacji Mateusza o śmierci Jezusa. Mamy zatem wspólny kontekst pasyjny. Po drugie, sam akt rozdarcia zostaje w nich podkreślony, choć na różne sposoby: rozdarcie szat poprzez stronę aktywną w relacji do participium dictum - rozdarcie zasłony poprzez ukazanie go jako aktu inaugurującego wydarzenia eschatologiczne związane z Bożą interwencją. Po trzecie, oba teksty znajdują się w kontekście arcykapłańskim. W pierwszej scenie, co 
oczywiste, za sprawą obecności samego arcykapłana, z kolei w drugiej scenie może wskazywać na to motyw zasłony, która kojarzyła się od razu z arcykapłanem, gdyż tylko on miał prawo przejść przez nią raz do roku w święto Jom Kippur (Dzień Przebłagania). Ponadto może na to wskazywać także uwydatniona przez Mateusza wzmianka o rozdarciu zasłony „z góry na dół” ${ }^{19}$, ponieważ jedyne miejsce, w którym mowa o rozdzieraniu czegokolwiek w ten sposób, dotyczy właśnie szat arcykapłana (Horajot 3, 5). Po czwarte, w obu tekstach akt rozdarcia jest wynikiem gniewu. W przypadku rozdarcia szat arcykapłana nie ma co do tego wątpliwości, gdyż tradycja starotestamentowa potwierdza zwyczaj tego rodzaju wyrażania gniewu w obliczu bluźnierstwa $(2 \mathrm{Krl}$ 18,30-19,1, por. Iz 36,22-37,1). Miszna zaś wręcz nakazuje tak czynić (Sanhedryn 7, 5). W przypadku rozdarcia zasłony natomiast na motyw gniewu wskazują przede wszystkim wydarzenia o charakterze eschatologicznym, o których mówili prorocy w kontekście sądu Bożego. Podobnie wskazuje na to struktura wersetu, która dzieli wydarzenia na negatywne i pozytywne - rozdarcie zasłony należy do tych pierwszych, i w dodatku je inauguruje. Z kolei biorąc pod uwagę fakt, że rozdarcie zasłony świątyni wskazuje na opuszczenie jej przez Boga, skutkiem tego opuszczenia było jej zburzenie w roku 70, co było widziane jako wyraz Bożego gniewu. Po piąte, w obu przypadkach przyczyną gniewu było prawdopodobnie bluźnierstwo. W pierwszym przypadku nie ma co do tego wątpliwości, gdyż sam Mateusz wiąże rozdarcie szaty z orzeknięciem przez arcykapłana bluźnierstwa. Tymczasem w drugim wypadku, zakładając że - jak sądzę ze względu na kontekst arcykapłański - zasłona jest odpowiednikiem szaty na zasadzie metafory, bluźnierstwo jawi się na różne

19 Mateusz w przeciwieństwie do Marka przestawia kolejność wyrazów w zdaniu, przesuwając na koniec zdania wyrażenie eis $\delta$ v́o ("na dwoje'), które u Marka poprzedza ả $\pi^{\text {' } \alpha \nu \omega \theta \varepsilon \nu ~ ह ै \omega \varsigma ~} \kappa \dot{\alpha} \tau \omega$ ('z góry do dołu'). 
sposoby. Przypomnijmy, że w czasach Jezusa za bluźnierstwo uważano: (1) naśmiewanie się z Boga, (2) przeklinanie Boga, (3) lekceważenie i umniejszanie mocy Boga. To wszystko zaś spotkało Boga w osobie Jego Syna, z którego szydzono i wyśmiewano się (np. Mt 27,29), którego przeklinano (np. Mt 27,39) i u którego lekceważono moc Bożą (np. Mt 12,24; Mt 27,40). Tak skumulowane bluźnierstwo i grzech na Jego Synu, który sam był oskarżany przez arcykapłana o bluźnierstwo przeciw Bogu, teraz zostaje uznane przez samego Boga za faktyczne bluźnierstwo przeciw Niemu samemu. W odpowiedzi na nie rozdziera zasłonę jako wyraz Jego gniewu. Rzecz jasna ktoś mógłby zauważyć, że w tym przypadku akt rozdarcia mógłby równie dobrze być wyrazem żalu nad śmiercią umiłowanego syna, co również odpowiada tradycji starotestamentowej (por. Rdz 37,34; 2 Sm 1,11-12). To prawda, jednak kontekst arcykapłański i eschatologiczny raczej nie wskazuje na żal, lecz gniew, a ponadto poczucie żalu nie wyklucza gniewu, wręcz przeciwnie - czasem go wręcz wzmaga.

W tym wszystkim jest tylko jeden problem, aczkolwiek bardzo poważny z punktu widzenia egzegezy biblijnej. Otóż Mateusz używa dwóch różnych czasowników na oznaczenie rozdarcia szat i zasłony. W pierwszym przypadku zostaje

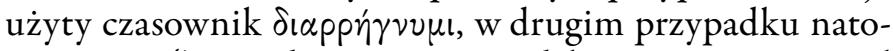
miast $-\sigma \chi i \zeta \omega$. Wydaje się więc, że gdyby Mateusz zamierzał zwrócić uwagę czytelnika na paralele tych dwóch aktów, najpierw arcykapłana, następnie samego Boga, wówczas użyłby w obu miejscach tego samego czasownika. Fakt ten sprawia, że pomimo wielu mniej lub bardziej oczywistych paraleli status podjętej korelacji wciąż nie może być większy niż hipotetyczny. Istnieją jednak okoliczności, które nieco łagodzą ten, jak się wydaję, definitywny i obosieczny kontrargument. Jak już zostało wspomniane w artykule (pkt 1.2.), $2 \mathrm{Krl}$ 18,13-19,13 opowiada o bluźnierczej mowie posłańca króla asyryjskiego, Sennacheryba, który z lekceważeniem wyrażał się o możliwym wybawieniu Izraela za sprawą mocy Boga 
YHWH. W odpowiedzi na usłyszane bluźnierstwo król Ezechiasz oraz wszyscy ci, którzy oznajmili mu bluźnierczą wypowiedź posłańca, w gniewie rozdarli swe szaty $(2 \mathrm{Krl}$ $18,37 ; 19,1)$. W tym miejscu LXX oddaje ich akt czasow-

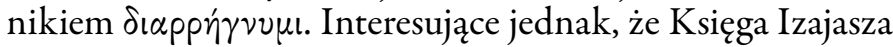
w wersji LXX, która relacjonuje tę samą historię w rozdziałach 36-37, używa na oddanie rozdarcia szat innego czasownika $\sigma \chi i \zeta \zeta(36,22 ; 37,1)$, a więc tego samego czasownika, który jest użyty przez Mateusza na opisanie rozdarcia zasłony świątyni. W tym świetle widzimy więc, że czasowniki $\delta ı \rho p \eta ́ \gamma \nu v \mu \iota$ i $\sigma \chi i \zeta \omega$ mogły być używane zamiennie na oznaczenie rozdarcia jako wyrazu gniewu w obliczu bluźnierstwa, i to nawet w tekstach mówiących o tym samym wydarzeniu. Co więcej, w tym samym miejscu hebrajski tekst Izajasza oddaje rozdarcie szat poprzez czasownik קרע, którego Miszna używa na oznaczenie rozdarcia szat arcykapłana wobec bluźnierstwa (Sanhedryn 7, 5). Ponadto Mateusz najczęściej korzystał z greckich tekstów Izajasza w swojej narracji o Jezusie, a to właśnie w Iz 36-37 użyty jest czasownik $\sigma \chi i \zeta \omega$ w kontekście bluźnierstwa, którym jest umniejszanie mocy Boga. Tymczasem z tego typu bluźnierstwem mamy do czynienia właśnie w przypadku rozdarcia zasłony przez Boga, co stwierdziliśmy już wcześniej. Być może więc Mateusz miał na uwadze ten fragment Izajaszowego tekstu i z tego względu użył takiego czasownika. Jednocześnie nie musiało być dla niego problemem użycie w tym wypadku dwóch różnych czasowników, podobnie jak nie było to problemem dla autorów LXX, którzy uczynili to samo, opowiadając o tym samym wydarzeniu. To oczywiście wciąż nie stanowi solidnego kontrargumentu, dlaczego Mateusz użył dwóch różnych czasowników, jeśli zamierzył dowodzoną tu paralelę. Tym niemniej nie pozwala to uznać proponowaną hipotezę za całkowicie bezpodstawną i absurdalną. 


\section{Podsumowanie}

Gest rozdarcia szat przez arcykapłana był wyrazem gniewu na usłyszane bluźnierstwo z ust Jezusa. Skutkiem tego bluźnierstwa był wyrok śmierci na Nim. Faktycznie jednak to nie sam Jezus zbluźnił, ale wszyscy ci, którzy nie rozpoznali w Nim i poprzez Jego dzieła samego Boga, który rozpoczął wcielać w życie plan zbawienia człowieka. Bóg w Jezusie nie tylko został odrzucony, ale świat zakpił z Niego i przeklął Go, nie wykazując wiary w Jego moc, nie tylko moc zwyciężenia zła, ale moc wierności przymierzu i miłości, która była podstawą i główną motywacją Jego ostatecznej interwencji zbawczej. To wszystko z kolei podchodziło pod ówczesne rozumienie bluźnierstwa wobec Boga. Bóg zatem, zgodnie ze zwyczajem, rozdarł z gniewu swoją widzialną szatę, tj. zasłonę świątyni, czyniąc to z góry do dołu jako odpowiedź na rozdarcie szat arcykapłana, który zgodnie z Miszną w ten sposób musiał ją rozedrzeć. Bezpośrednim skutkiem rozdarcia zasłony był rozdźwięk w dotychczasowej relacji z etnicznym Izraelem, skupionej wokół kultu świątynnego, pośrednim skutkiem zaś było zburzenie jej w roku 70 przez okupujących Izrael Rzymian. Z kolei przyczyną rozdarcia zasłony był gniew Boga, zapowiadany niegdyś przez proroków, a teraz w końcu rozlany w obliczu największego bluźnierstwa w historii świata. Na taką korelację tych dwóch aktów „rozdarcia” wskazuje kontekst pasyjny, eschatologiczny, a także arcykapłański. Problemem jest jednak fakt, że kontekst arcykapłański musi zakładać, że Mateusz znał tradycje, które ostatecznie znalazły się w Misznie, co udowodnić jest bardzo trudno. Ponadto Mateusz używa dwóch różnych czasowników na opisanie aktu „rozdarcia”. W mojej ocenie, Mateuszowi prawdopodobnie zależało bardziej na podkreśleniu skutku rozdarcia zasłony, tj. rozdźwięku w relacji Boga z etnicznym Izraelem w oparciu o kult świątynny, dlatego podporządkował czasownik temu celowi. Jednak za sprawą wielu innych szczególów, które ukazaliśmy w analizie porównawczej, nie zapomniał 
on o celu drugorzędnym, czyli wskazaniu przyczyny rozdarcia, tj. gniewu Bożego. Wiedząc zaś, że czasowniki $\sigma \chi i \zeta \omega$

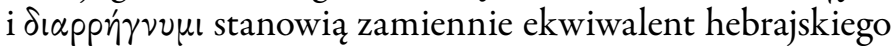
czasownika קרע, o czym świadczy LXX, mógł pozwolić sobie na takie rozróżnienie, nie czyniąc tego całkowicie kosztem celu drugorzędnego. Dzięki takiemu zabiegowi, mógł poprzez ten jeden akt rozdarcia wskazać zarówno na skutek, jak i na przyczynę gniewu Bożego.

\section{BIBLIOGRAFIA}

Cassius Dio, Roman History. VI. Books 51-55 (Loeb Classical Library 83; London - New York, NY: Harvard University Press 1917).

Cassius Dio, Roman History. VII. Books 56-60 (Loeb Classical Library 175; London - New York, NY: Harvard University Press 1924).

Brown R.E., The Death of the Messiab: From Gethsemane to the

Grave (New York, NY: Doubleday 1994) I.

Evans A.C. - Carlston E.C., From Synagogue to Ecclesia: Matthew's Community at the Crossroads (WUNT 334; Tübingen: Mohr Siebeck 2014).

Ginzberg L., „Akiba ben Joseph”, Jewish Encyclopaedia (red. I. Singer) (New York: Funk and Wagnalls Company 19011916) 304-310.

Meier P.J., „The Historical Jesus and the Historical Law: Some

Problems within the Problem", The Catholic Biblical Quarterly 65/1 (2003) 52-79.

Meyers C., "Veil of the Temple”, The Anchor Bible Dictionary (red. D.N. Freedman) (New York, NY: Doubleday 1992) VI, 9241.

Neusner J., Judaism: The Evidence of the Mishnah (Chicago: University of Chicago Press 1981).

Sanders E.P., Jewish Law from Jesus to the Mishnah: Five Studies (Philadelphia: Trinity 1990). 
The Mishnah (red. H. Danby) (Oxford: Oxford University Press 1933).

Michą Klukowski, mgr lic. teologii, absolwent Wydziału Teologicznego na Uniwersytecie Opolskim, obecnie doktorant w Instytucie Nauk Biblijnych na Katolickim Uniwersytecie Lubelskim Jana Pawła II. 